\title{
HUBUNGAN KOMPETENSI SOSIAL GURU KELAS TERHADAP PENANAMAN PENDIDIKAN KARAKTER SISWA DI SEKOLAH DASAR
}

\author{
Maslan \\ maslanpangean08@gmail.com \\ SD Negeri 014 Pulau Rengas, Kuantan Singingi, Indonesia
}

\begin{abstract}
Teachers play a very important role in improving the quality of education. Therefore, professional teachers are required to always improve their competence, one of them is social competence. Learning will not run well and effectively if the teacher is not able to develop social competence. The purpose of this study is to describe and find out the relationship of teacher social competence in inculcating student character education. This research was carried out at SD Negeri 014 Pulau Rengas. This type of research is a qualitative descriptive. Methods of data collection using questionnaires, interviews, field notes. The results showed that the social competence of teachers obtained an average score of $90 \%$ in the excellent category and the assessment of students' character education planting had an average value of $85 \%$ in the very good category. The results of the study prove the teacher's social competence is very important in instilling character education in elementary school students 014 Pulau Rengas
\end{abstract}

Keywords: social competence, character education

\section{ABSTRAK}

Guru memegang peranan yang sangat penting dalam meningkatkan kualaitas pendidikan. Oleh karena itu, guru yang profesional dituntut untuk selalu meningkatkan kompetensi dirinya, salah satunya kompetensi sosial. Pembelajaran tidak akan berjalan dengan baik dan efektif apabila guru tidak mampu mengembangkan kompetensi sosialnya. Tujuan penelitian ini adalah untuk mendeskripsikan dan mengetahui hubungan kompetensi sosial guru dalam penanaman pendidikan karakter siswa. Penelitian ini dilaksanakan di SD Negeri 014 Pulau Rengas. Jenis penelitian ini merupakan deskriptif kualitatif. Metode pengumpulan data menggunakan angket, wawancara, catatan lapangan. Hasil penelitian menunjukkan bahwa kompetensi sosial guru memperoleh nilai rata-rata 90\% katagori sangat baik dan penilaian penanaman pendidikan karakter siswa memiliki nilai rata-rata $85 \%$ kategori sangat baik. Hasil penelitian membuktikan kompetensi sosial guru sangat penting dalam menanamkan pendidikan karakter pada siswa sekolah dasar SD Negeri 014 Pulau Rengas.

Kata Kunci: kompetensi sosial, pendidikan karakter

\begin{tabular}{|c|c|c|}
\hline Submitted & Accepted & Published \\
\hline 19 Agustus 2019 & 31 Oktober 2019 & 12 November 2019 \\
\hline
\end{tabular}

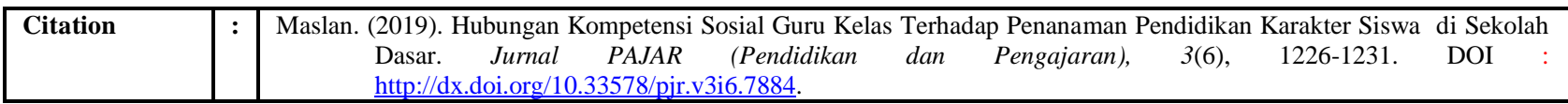

\section{PENDAHULUAN}

Guru memegang peranan yang sangat penting di dalam menentukan keberhasilan dari sebuah proses pendidikan. Pada dasarnya guru merupakan pembimbing siswa dalam rangka mengembangkan, membentuk karakter serta mengembangkan potensinya dalam mencapai tujuan pendidikan yang diinginkan. Berdasarkan Undang-Undang No 14 Th 2005 tentang guru dan dosen seorang guru yang professional hendaknya memiliki 4 kompetensi yaitu : 1) Kompetensi Paedagogik, 2) Kompetensi Kepribadian, 3) Kompetensi Profesional, dan 4) Kompetensi Sosial.
Keempat kompetensi guru di atas saling berhubungan antara satu dengan yang lainnya. Namun, di dalam pembelajaran yang sangat perlu diperhatikan adalah kompetensi sosial. Kompetensi sosial itu sendiri merupakan salah satu kemampuan guru dalam bagaimana berkomunikasi dan berinteraksi secara aktif dan efektif dengan lingkungan sekolah maupun di luar lingkungan sekolah (Wibowo dan Hamrin, 2012). Seorang guru harus berusaha mengembangkan komunikasi dengan siswanya secara berkelanjutan sehingga terjalin komunikasi dua arah yang baik. Dengan adanya komunikasi 
dua arah, diharapkan guru dapat dengan mudah membimbing, mengajarkan, serta membangun dan menanamkan pendidikan karakter terhadap siswa, sehingga pendidikan karakter siswa dapat dipantau secara lebih baik dan siswa dapat mengembangkan karakternya secara lebih efektif pula di dalam proses pembelajaran.

Proses pembelajaran tidak akan berjalan dengan baik dan efektif apabila guru tidak mampu mengembangkan kompetensi sosialnya dengan baik pula (Rahmawati, 2018). Oleh karena itu, guru haruslah memiliki sebuah kemampuan dalam bergaul atau pun berkomunikasi dengan siswa. Tidak hanya itu, guru juga harus dapat berkomunikasi dengan sesama pendidik, tenaga kependidikan, orang tua/ wali siswa, dan masyarakat sosial. Kemampuan inilah yang sering disebut dengan kompetensi sosial guru.

\section{KAJIAN TEORETIS}

Karakter merupakan cerminan diri seseorang dari cara bersikapnya. Menurut Ratna (dalam Kesuma, 2012), pendidikan karakter adalah sebuah usaha untuk mendidik anak-anak agar dapat mengambil keputusan dengan bijak dan memerhatikannya dalam kehidupan sehari-hari, sehingga mereka dapat memberikan kontribusi yang positif kepada lingkungannya. Pengertian lainnya dikemukakan oleh Gaffar (2010:1), pendidikan karakter adalah sebuah proses transformasi nilai-nilai kehidupan untuk ditumbuh kembangkan dalam kepribadian seseorang sehingga menjadi satu dalam perilaku kehidupan orang tersebut. Lebih lanjut, pendidikan karakter merupakan sebuah kemampuan dalam memahami, membentuk, memelihara, menanamkan nilai-nilai etik berupa pengetahuan, perasaan, dan perilaku

\section{METODE PENELITIAN}

Penelitian ini dilaksanakan di SD Negeri 014 Pulau Rengas, Kecamatan Pangean. Penelitian ini merupakan penelitian Tindakan Sekolah (PTS). PTS merupakan suatu prosedur penelitian yang diadaptasi dari penelitian tindakan kelas (Azmi, 2019). Tujuan penelitian
Seorang guru yang memiliki kompetensi sosial akan diterima baik oleh siswanya (sekolah) dan maupun di lingkungan masyarakat sekitar. Hal ini terjadi karena guru mampu berkomunikasi dengan baik di masyarakat, serta mampu menyesuaikan diri dengan nilai-nilai yang menjadi pegangan masyarakat di mana ia bertugas, serta mampu mengatasi masalah sosial yang timbul di masyarakat. Karena guru merupakan panutan baik bagi siswanya maupun bagi masyarakat sekitarnya (Rini, 2017).

Melihat pentingnya peran komptensi sosial guru dalam mewujudkan tujuan pendidikan seperti yang telah diuraikan di atas maka tujuan penelitian ini adalah untuk mendeskripsikan dan mengetahui hubungan kompetensi sosial guru dalam penanaman pendidikan karakter siswa.

tentang moral atau perilaku yang dapat dilihat dari kebiasaannya, sehingga mereka dapat memberi kontribusi yang positif terhadap lingkungannya, (Afendi, 2019).

Kesuma (2012:9) mengemukakan tiga tujuan pendidikan karakter sebagai berikut: (1) menguatkan dan mengembangkan nilai-nilai kehidupan yang dianggap penting dan perlu sehingga menjadi kepribadian kepemilikan siswa yang khas sebagaimana nilai-nilai yang dikembangkan, (2) mengoreksi perilaku siswa yang tidak bersesuaian dengan nilai-nilai yang dikembangkan oleh sekolah, dan (3) membangun koneksi yang harmoni dengan keluarga dan masyarakat dalam memerankan tanggung jawab karakter bersama.

ini untuk melihat kompetensi sosial guru dalam menanamkan pendidikan karakter siswa.

Jenis penelitian yang digunakan adalah penelitian deskriptif kualitatif. Instrumen yang digunakan dalam penelitian ini adalah: (1) Observasi, lembar observasi digunakan untuk melihat proses pembelajaran yang dilakukan 
guru di dalam kelas. (2) Wawancara, peneliti melakukan wawancara untuk mengetahui secara jelas bagaimana kompetensi sosial guru dan nilai karakter siswa, tentang pelaksanaan pembelajaran, cara dalam mengatasi berbagai karakter siswa yang berbeda-beda. (3) Angket, angket penelitian yang berisi serangkaian pertanyaan atau pernyataan untuk memperoleh informasi yang harus dijawab responden secara bebas sesuai pendapatnya. (4) Catatan lapangan, peneliti menggunakan catatan tertulis dalam penelitian ini yang berisi tentang apa yang didengar, dan apa yang dilihat untuk pengumpulan data.

\section{HASIL DAN PEMBAHASAN}

Kompetensi sosial guru dalam berkomunikasi secara efektif dengan siswa melalui kegiatan pembelajaran di SD Negeri 014
Teknik analisis data dalam penelitian ini adalah (1) Reduksi data, data yang diperoleh dari laporan jumlahnya cukup banyak, untuk itu maka perlu dicatat secara teliti dan rinci. (2) Penyajian data penelitian kualitatif bisa dilakukan dalam bentuk uraian singkat, bagan, hubungan antara kategori, dan sejenisnya. (3) Verifikasi atau penyimpulan data, kesimpulan awal yang dikemukakan masih bersifat sementara, dan akan berubah bila ditemukan bukti-bukti yang kuat yang mendukung pada tahap berikutnya.

Tabel 1. Hasil Observasi Kompetensi Sosial Guru

\begin{tabular}{clcc}
\hline No & \multicolumn{1}{c}{ Indikator } & Persentase \% & Kategori \\
\hline 1 & $\begin{array}{l}\text { Guru mampu berkomunikasi secara } \\
\text { lisan dan tulis secara aktif, kreatif, } \\
\text { menyenangkan, serta santun. }\end{array}$ & $89 \%$ & Sangat Baik \\
\hline 2 & $\begin{array}{l}\text { Bersikap dan bertindak objektif } \\
\text { terhadap siswa }\end{array}$ & $95 \%$ & Sangat Baik \\
\hline 3 & $\begin{array}{l}\text { Empatik dan Santun berkomunikasi } \\
\text { dengan siswa, pimpinan, rekan } \\
\text { sejawat, wali murid, serta masyarakat } \\
\text { sekolah. }\end{array}$ & $85 \%$ & Sangat Baik \\
\hline 4. & Mampu bekerja sama secara optimal & $92 \%$ & Sangat Baik \\
\hline
\end{tabular}

Berdasarkan hasil observasi pada indikator guru mampu berkomunikasi secara lisan dan tulis secara aktif, kreatif, menyenangkan, serta santun, diketahui hasil observasi kompetensi sosial guru mendapat persentase sebesar $89 \%$ kategori sangat baik. Ini terjadi karena guru telah mampu berkomunikasi secara lisan dan tulis secara aktif kreatif menyenangkan. Hal ini terlihat dari guru selama melaksanakan pembelajaran mengembangkan sikap komunikasi dialogis terhadap siswa. Di dalam proses pembelajaran berlangsung juga terjadi tanya jawab pada saat menyampaikan materi secara santun dan menyenangkan. Pemakaian bahasa di dalam proses pembelajaran juga telah disesuaikan guru dengan tahap perkembangan siswa serta guru di dalam menegur siswa telah menggunakan katakata yang baik. Sesuai dengan pendapat Allen (2008) bahwa perkembangan bahasa siswa usia sekolah dasar telah menyelesaikan sebagian besar perkembangan bahasanya, senang berbicara dan berargumentasi, struktur bahasanya lebih panjang dan kompleks, menjadi pendengar yang suka berpikir, mengerti dengan makna tersirat, dan menguasai beberapa gaya bahasa. Lebih lanjut menurut Yusuf dan Sugandhi (2011:62) siswa usia sekolah dasar sudah gemar membaca atau mendengar secara kritis dan berpikir lebih maju. 
Maka dari itu, berdasarkan observasi pada indikator berkomunikasi secara lisan dan tulis secara aktif, kreatif, menyenangkan, serta santun telah berjalan dengan baik.

Indikator kedua, Bersikap dan bertindak objektif terhadap siswa mendapat persentase sebesar 95\% kategori sangat baik. Hal ini terjadi karena guru di dalam bertindak terhadap siswa telah objektif, serta tidak diskriminatif. Hal ini terlihat dari guru tidak membeda-bedakan siswa baik secara kelamin, agama, ras, kondisi fisik, latar belakang keluarga, dan status sosial ekonomi siswa. guru juga menunjukkan sikap terbuka terhadap masyarakat sekitar, menjalin hubungan yang baik dengan wali murid. Ini selaras dengan jurnal hasil penelitian yang dilakukan oleh Junaiah (2016) yang menyatakan bahwa arti semakin baik kecerdasan emosional dan spiritual guru, semakin baik dampak yang dihasilkan dari peningkatan kompetensi sosial guru, terhadap siswa, walimurid, serta masyarakt. Hal ini telah membuktikan bahwa guru telah objektif, serta tidak diskriminatif terhadap siswa.

Indikator ketiga, empatik dan santun berkomunikasi dengan siswa, pimpinan, rekan sejawat, wali murid, serta masyarakat sekolah mendapat persentase sebesar $85 \%$ kategori sangat baik. Hal ini terjadi karena sikap empatik dan santun menjadi hal yang paling penting dalam berkomunikasi dan guru telah menunjukan sikap tersebut di dalam berkomunikasi dan guru telah dapat memposisikan dirinya dengan baik terhadap lawan bicaranya. Sikap dan perilaku serat tutur bahasa akan menentukan atmosfer komunikasi. Sikap empatik dan santun dapat diaplikasikan dalam cara melakukan kritik, teguran, dan nasehat. Bahasa menjadi solusi alternatif dalam menyampaikan kritik, teguran, dan nasehat tersebut. Bahkan empatik dan santun merupakan cara dan pendekatan yang dilakukan guru dalam melakukan komunikasi dengan siswa, sesama guru, dan masyarakat sekolah. Dalam hal ini guru telah mampu melaksanakannya dengan baik.

Indikator keempat, mampu bekerja sama secara optimal mendapat persentase sebesar $92 \%$ kategori sangat baik. Hal ini terlhat dari, kemampuan guru dalam berinteraksi dengan siswa, teman sejawat, pimpinan, dan wali murid dalam bekerja sama menyiapkan berbagai kegiatan lomba yang diikuti sekolah. Guru berperan aktif ikut membantu menyiapkan kostum perlombaan, atribut perlombaan, serta mengantar siswa mengikuti lokasi perlombaan. Sejalan dengan pendapat Keengwe (dalam Junaiah, 2016) yang menyatakan bahwa guru memiliki sikap yang ramah, penuh semangat dan hangat dalam berinteraksi dengan siswa, rekan sejawat, pimpinan, serta masyarakat sekolah akan dapat membangkitkan motivasi kemajuan pendidikan, rasa senang sikap peduli, sikap akomodatif, dan sikap bekerjasama. Hal ini membuktikan indikator mampu bekerja sama secara optimal telah berjalan dengan baik.

Penilaian karakter siswa diperoleh dari hasil pengamatan karakter siswa. Data diperoleh dari lembaran observasi yang diisi oleh observer. Adapun nilai karakter yang muncul selama dalam selama proses penelitian berlangsung adalah religius, jujur, disiplin, kerja sama, kreatif, dan tanggung jawab. Hasil observasi terhadap karakter siswa dapat dilihat secara ringkas pada tabel 2 berikut ini:

Tabel 2. Hasil Penilaian Karakter Siswa

\begin{tabular}{llcc}
\hline No. & \multicolumn{1}{c}{$\begin{array}{c}\text { Nilai Karakter yang } \\
\text { Dikembangkan }\end{array}$} & Nilai \% & Kategori \\
\hline 1. & Religius & 84 & Sangat Baik \\
\hline 2. & Disiplin & 87 & Sangat Baik \\
\hline 3. & Kerja Sama & 89 & Sangat Baik \\
\hline 4. & Kreatif & 75 & Baik \\
\hline 5. & Tanggung Jawab & 89 & Sangat Baik \\
\hline Rata-rata \% & $\mathbf{8 5}$ & Sangat Baik \\
\hline
\end{tabular}


Dari data hasil angket di atas dapat diketahui bahwa tingkat nilai pendidikan karakter siswa termasuk dalam kategori sangat baik. Nilai religius siswa mendapatkan persentase sebesar $84 \%$ dalam kategori sangat baik. Hal ini terjadi karena, sebelum dan sesudah pembelajaran siswa telah melaksanakan berdoa bersama. Siswa di dalam berteman tanpa membedakan agama. Siswa dan guru selalu melakukan ibadah bersama (seperti shalat), selain itu siswa juga suka memberi atau menolong sesama jika ada yang kesulitan. Ini terjadi tidak lepas dari pengaruh dari guru mereka, di mana guru merupakan contoh yang menjadi panutan bagi mereka.

Karakter disiplin siswa mendapat nilai 87\% kategori sangat baik. Hal ini terjadi disebabkan oleh rata-rata semua siswa telah mengikuti peraturan yang ada di sekolah maupun di dalam kelas, siswa selalu memakai pakaian seragam lengkap dan rapi, tidak perna terlambat datang ke sekolah ataupun masuk ke dalam kelas, dan selalu mengumpulkan tugas tepat waktu.

Karakter kerja sama siswa mendapat nilai $89 \%$ kategori sangat baik. Ini dapat dilihat dari mengerjakan kerja kelompok dengan teliti dan rapi, mencari informasi di luar sekolah dengan bersama-sama, mencatat dengan sungguhsungguh sesuatu yang dibaca, diamati, dan didengar untuk kemudian didiskusikan didalam kelompok mereka.

Karakter kreatif siswa mendapat nilai 75\% kategori baik. Ini terlihat dari proses pembelajaran berlangsung seperti membuat berbagai kalimat baru dari sebuah kata tanpa dikomunikasikan terlebih dahulu oleh gurunya, bertanya tentang sesuatu yang berkenaan dengan pelajaran tetapi diluar cakupan materi pelajaran, melakukan bersih-bersih kelas setelah pembelajaran selesai.

Karakter tanggung jawab siswa mendapat nilai $89 \%$ kategori sangat baik, ini terjadi karena siswa selalu menylesaikan tugas yang diberikan, tidak takut untuk mengakui kesalahan jika mereka melakukan kesalahan, selalu melaksanakan tugas yang menjadi kewajibannya di kelas seperti piket kebersihan.

Dari hasil ini membuktikan bahwa kompetensi sosial guru kelas mampu menanamkan pendidikan karakter siswa. Hal ini dapat dilihat dari hasil analisis sebagai berikut:

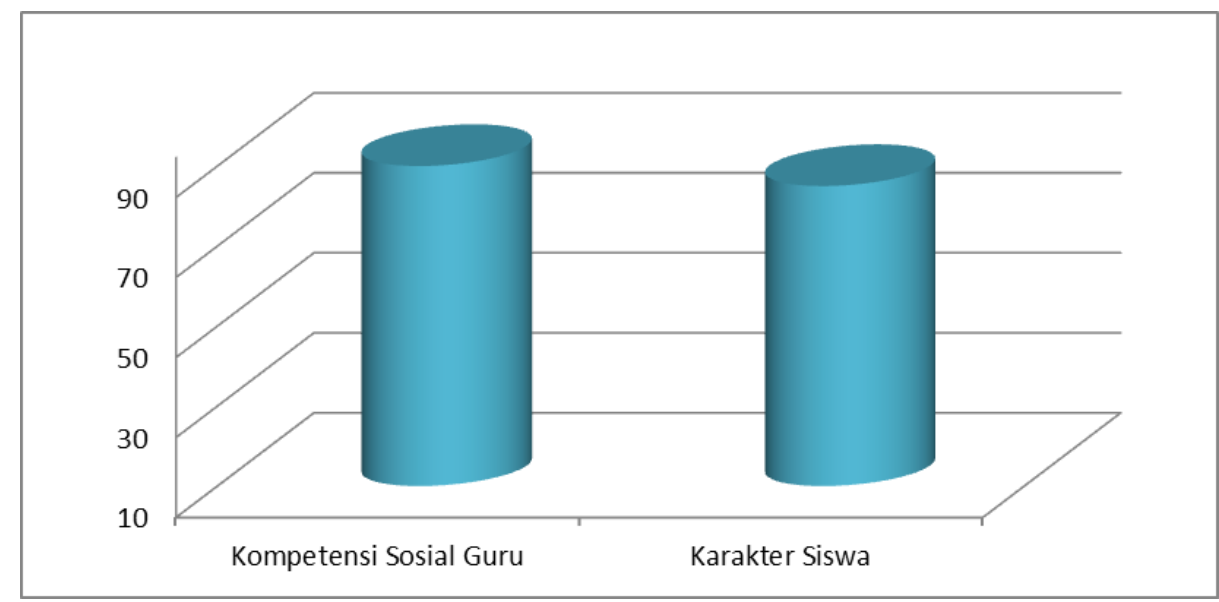

Gambar 1. Kompetensi Sosial Guru dan Karakter Siswa

Dari analisis data di atas menunjukkan bahwa kompetensi sosial guru dan pendidikan karakter siswa sama-sama mendapatkan persentase yang tinggi. Dapat dikatakan bahwa kompetensi sosial guru sangat penting dalam menanamkan pendidikan karakter siswa. Hal ini membuktikan bahwa siswa memiliki rasa hormat dan santun terhadap guru sehingga keduanya baik guru maupun siswa memiliki interaksi yang positif serta baik dalam menghargai dan saling menghormati. 


\section{SIMPULAN DAN REKOMENDASI}

Berdasarkan temuan hasil penelitian dan pembahasan yang mengacu pada tujuan penelitian di SD Negeri 014 Pulau Rengas, Kecamatan Pangean, maka diperoleh hasil kesimpulan kompetensi sosial guru memperoleh nilai rata-rata 90\% katagori sangat baik dan penilaian penanaman pendidikan karakter siswa memiliki nilai rata-rata $85 \%$ kategori sangat baik. Hasil ini membuktikan kompetensi sosial guru sangat penting dalam menanamkan pendidikan karakter pada siswa sekolah dasar SD Negeri 014 Pulau Rengas.

\section{DAFTAR PUSTAKA}

Afendi, N., Mudjiran., Arif, D., \& Misliati. (2019). Development of Teaching Materials Reading Comprehension Based On Cooperative Integrated Reading and Composition (CIRC) Strategy As Character Education In Class VI Elementary School. Jurnal PAJAR (Pendidikan dan Pengajaran), 3(5), 983-994. DOI: http://dx.doi.org/10.33578/pjr.v3i5.7810.

Allen, K.E. (2008). Profil Perkembangan Anak. Jakarta: Indeks.

Azmi. (2019). Meningkatkan Disiplin Guru dalam Kehadiran ke Sekolah dan Mengajar di Kelas Melalui Penerapan "Reward and Punishment". Jurnal PAJAR (Pendidikan dan Pengajaran), 3 (3), 550-559. DOI: http://dx.doi.org/10.33578/pjr.v3i3.7117.

Gaffar, F. (2010). Pendidikan Karakter Berbasis Islam. Yogyakarta: Pustaka Pelajar.

Junaiah. (2016). Pengelolaan Kompetensi Sosial Guru Sekolah Dasar Negeri 2 Mojorebo Kecamatan Wirosari Kabupaten Grobogan. Surakarta: Universitas Muhammadiyah.
Dari hasil penelitian dan kesimpulan di atas, peneliti memberikan beberapa saran antara lain bagi siswa, supaya terus meningkatkan nilainilai pendidikan karakter dalam kehidupan seharihari baik di rumah, di sekolah, maupun di masyarakat. Bagi pendidik, agar dapat lebih meningkatkan lagi kompetensi yang wajib dimiliki oleh guru sehingga mampu memotivasi siswa untuk bersikap lebih baik lagi dan lebih menekankan kepada siswa pentingnya nilai-nilai karakter bagi kehidupan siswa nantinya.

Kesuma, D., dkk. (2012). Pendidikan Karakter. Bandung: Remaja Rosda Karya.

Rahmawati, A., \& C. Indah, N. Kompetensi Sosial Guru dalam Berkomunikasi Secara Efektif dengan Siswa Melalui Kegiatan Pembelajaran Bahasa Indonesia di SD Negeri Rejowinangun 3 Kotagede Yogyakarta. Trihayu: Jurnal Pendidikan Ke-SD-an, 4(3), 338-392.

Rini, E.S. (2017). Analisis Kompetensi Guru pada Guru Sekolah Dasar. Online http://erisusilorini97.blogs.uny.ac.id.

Undang-Undang Republik Indonesia No. 14 Tahun 2005 tentang Guru dan Dosen.

Wibowo \& Hamrin, A. (2012). Menjadi Guru Berkarakter: Strategi Membangun Kompetensi dan Karakter Guru. Yogyakarta: Pustaka Pelajar.

Yusuf., \& Sugandhi, N.M. (2011). Perkembangan Peserta Didik. Jakarta: Raja Grafindo Persada. 